\title{
SD 0 S COMBRIDGE
}

Review

Source: The Journal of Hellenic Studies, Vol. 41, Part 1 (1921), pp. 151-152

Published by: The Society for the Promotion of Hellenic Studies

Stable URL: http://www.jstor.org/stable/624803

Accessed: 26-06-2016 06:45 UTC

Your use of the JSTOR archive indicates your acceptance of the Terms \& Conditions of Use, available at

http://about.jstor.org/terms

JSTOR is a not-for-profit service that helps scholars, researchers, and students discover, use, and build upon a wide range of content in a trusted digital archive. We use information technology and tools to increase productivity and facilitate new forms of scholarship. For more information about JSTOR, please contact support@jstor.org.

The Society for the Promotion of Hellenic Studies, Cambridge University Press are collaborating with JSTOR to digitize, preserve and extend access to The Journal of Hellenic Studies 


\section{NOTICES OF BOOKS}

Tales of Aegean Intrigue. By J. C. Lawson. Pp. 271. London: Chatto \& Windus, 1920. 12s. $6 d$.

The writer of these tales served during the War as Naval Intelligence Officer in Crete, and had consequently exceptional opportunities of applying his wide knowledge of the Greeks and their ways to the picturesque incidents which such service provokes. He seems to have taken an active part in the events which resulted in the National Defence Movement, and the establishment of a Venizelist administration in insular Greece. As he confines himself to what he himself saw or experienced, some knowledge of the main course of events is presupposed, if these 'Tales' are to be fitted into their place in it. He has clear and emphatic views on some defects in our organisation and war-policy, which are commended to those whom they concern. Of less ephemeral interest are the examples of propaganda-literature and mock-ballad in local dialect; and those who have seen other specimens will wish Mr. Lawson had printed more.

A Description of the Monuments of Cyprus. By George Jefrrey, F.S.A. Pp. 467, 37 text-illustrations, 5 plates. Nicosia: Government Printing Office, 1918. 7s. $6 d$.

Mr. Jeffrey has been for many years Inspector of Ancient Monuments in Cyprus, and has exceptionally detailed acquaintance with architectural remains of all periods in the island. This handbook, therefore, is based on close personal observations throughout, and is a most valuable record of the present state of the monuments which it describes. The brief Introduction brings together all the general information as to the administration and topography of the island, which is necessary for the purposes of such an archaeological survey, with a select bibliography, list of maps of Cyprus, and outlines of a classification of the ancient buildings by period, and style, and purpose.

The body of the book is arranged topographically, and would serve therefore as a guide, as well as inventory, for any student who might follow in the author's steps; and as even the smaller settlements are distributed in accordance with natural features, they fall naturally into groups along the principal routes. At the end of the book are notes on the history and chronology of Cyprus, on mediaeval costume (in relation to the sculptured tombs of the period) and on the Venetian officials whose names are likely to be met in inscriptions. There is a full index; adequate plans, and a few well-selected photographs.

Mr. Jeffrey is much to be congratulated on the completion of this important and very handy volume. It reveals, as nothing else could, the wealth of ancient remains in this curious region, and the devoted enthusiasm which the author has devoted to their study and conservation.

J. L. M.

Under the Turks in Constantinople. By G. F. Аввотт. Pp. 418. London : Macmillan \& Co., 1920. 18s.

This book contains a record of the Embassy of Sir John Finch to Turkey, 1674 to 1681. It has a commendatory Foreword by Lord Bryce, and as a frontispiece a reproduction of the portrait of Finch by Carlo Dolci. 
Mr. Abbott has taken much pains over this record, and appears to have digested the State Papers of the period with success. It is a careful and detailed account of the activities of one of our Ambassadors-a man of good brains and considerable energywho was in the difficult position of being in almost equal shares the servant of the King and the Levant Company. The story of his tribulations in his contact with the corrupt and dilatory Turkish officials makes interesting reading.

There are not so many details of seventeenth-century Turkish life and manners as could have been hoped, but this deficiency may be supplied by a reading of Mr. G. E. Hubbard's The Day of the Crescent, published by the Cambridge University Press last year; the two books taken together enable the reader to reconstruct Turkish life in that century as far as an outsider could ever appreciate it.

As a point of exceptional interest attention may be.drawn to the fact that our Ambassadors in Turkey appear to have exercised arbitrary authority over all British subjects; thus, if an Englishman conducted himself in a manner prejudicial to the peace or the interests of the 'Nation,' as the Community was called, the Ambassador would sometimes go so far as to expel the delinquent from the Turkish dominions.

Sir John Finch is of some importance in the history of our relations with Turkey at any rate up to the War, and in spite of the humiliating reception with which he met from Ahmed Kuprili on his arrival, he appears soon to have succeeded in gaining the Grand Vizier's goodwill, and it was he who obtained for us the English capitulations as they existed up to 1914. After Kuprili's death, under the administration of the terrible Kara Mustapha extortion became more rampant still, and Finch had to fight hard for the interest of his nation, using bribes for Turkish officials and the practice (of which Mr. Abbott does not say much) of 'battulation'; this was a kind of boycott under which the Ambassador prohibited all Englishmen from trading with a particular Turk, or even sometimes with a whole class of Turks.

There is room for another volume to show how the old grants made by Kuprili to Finch were later interpreted to allow far greater privileges than they were at first intended to confer. In the time of the later Stuarts, and even of the early Hanoverian Kings, no extra-territoriality was allowed to Englishmen, except in cases of lawsuits among themselves, and evidence appears that where a Turk was concerned the Englishman as a matter of course submitted to Turkish jurisdiction; owing, however, to the customary carelessness of the Turks, we were gradually allowed to wrest the capitulations into a sense vastly beyond their original meaning, and in the end we claimed for our subjects almost complete immunity from Turkish jurisdiction; usage, however, is so thoroughly recognised in Turkey as having fully the same force as law, that by virtue of this well-understood principle we were entitled to claim for Sir John Finch's capitulations the liberal interpretation which long custom conferred upon them.

The Idylls of Theocritus. With Introduction and Notes by R. J. Cholmeley. New edition. Pp. 449. London : G. Bell \& Sons, 1919. 18s. $6 d$. net.

The first edition of this well-known book supplied a long-felt want when it appeared in 1901. Until then there was no good English commentary on Theocritus, the notes in Kynaston's school edition being of a very elementary character. Those students who were able to read German notes were fairly well provided for by Hiller's edition (Teubner, 1881), which is a model of good sense and sobriety. Unfortunately, it was never reprinted, and in course of time has become difficult to procure. It is now, also, out of date, since it does not take into account new facts and theories which have accumulated since 1881, including contributions of Hiller himself. To this day Germany does not possess a modern commentary, though a great deal of work has been done on the text and subject matter.

Cholmeley published his book some seven years after leaving Oxford. During this time he had been occupied in teaching, first at the City of London School, and afterwards in South Africa, where he fought in the Boer War. He was prevented by military service from seeing it through the Press, and it contained a number of misprints and some slips, 